\title{
Strategies in umbilical cord-derived mesenchymal stem cells expansion: influence of oxygen, culture medium and cell separation
}

\author{
Antonina Lavrentieva ${ }^{1 *}$, Tim Hatlapatka ${ }^{1}$, Ramona Winkler ${ }^{1}$, Ralf Hass ${ }^{2}$, Cornelia Kasper $^{2}$ \\ From 22nd European Society for Animal Cell Technology (ESACT) Meeting on Cell Based Technologies \\ Vienna, Austria. 15-18 May 2011
}

\section{Background}

Mesenchymal stem cells (MSC) from different sources attract tremendous interest in cell-based therapies for their ability to differentiate into different cell lineages. MSC are already used in clinical trials as cell therapy [1]. In comparison to other "classical" sources of MSC (e.g. bone marrow and adipose tissue), the umbilical cord (UC) matrix has great potential, since there are no ethical limitations, risks for the donor or problems with variety of donor age [2]. However, a large numbers of cells (about $10^{6}$ cells per $1 \mathrm{~kg}$ body weight) are required which may still limit the implant preparation for clinical applications. Thus, strategies for the expansion of MSC must be well defined and controlled conditions need to be developed and established for reproducible production of cells under GMP conform conditions. Conventional in vitro cell cultivation is carried out under ambient oxygen concentration $\left(21 \%\right.$ of $\left.\mathrm{O}_{2}\right)$ which is defined as "normoxic". MSC in vivo usually are not exposed to such a high concentration of oxygen. In our work we studied the influence of oxygen concentration on the long-term as well as glucose and oxygen concentration on the short-term cultivation and expansion of UC-MSC.

\section{Materials and methods}

UC-MSC were isolated from whole human umbilical cords using an explant culture approach and characterised as described earlier $[3,4]$. For the long-term cultivation, MSC from the same donor were isolated and subsequently cultivated in two different oxygen

\footnotetext{
* Correspondence: kasper@iftc.uni-hannover.de

'Leibniz University Hannover, Institute of Technical Chemistry, Callinstr. 5, D30167 Hannover

Full list of author information is available at the end of the article
}

concentrations (5\% and 21\%). After isolation, cells were seeded at a density of 2000 cells $/ \mathrm{cm}^{2}$ in $25 \mathrm{~cm}^{2}$ cell culture flasks (Corning, Germany) and sub-cultivated every 3-4 days over 25 passages. Cell numbers were estimated at the end of each passage and cumulative population doublings were calculated for each culture conditions. MSC were cultivated in $\alpha$ MEM containing $1 \mathrm{~g} / \mathrm{l}$ glucose (Biochrom, Germany), 10\% allogenic human serum (provided by the Institute of Transfusion Medicine, Medical University Hannover, Germany) and $50 \mu \mathrm{g} / \mathrm{ml}$ gentamicin (PAA Laboratories $\mathrm{GmbH}$ ). To reveal the influence of glucose concentration on the proliferation capacities of UC-MSC under different oxygen concentrations, cells were seeded in 6-well plates (Sarstedt, Germany) at a density of 700 cells $/ \mathrm{cm}^{2}$ in $\alpha$ MEM $(1 \mathrm{~g} / 1$ glucose $)$ and DMEM (4.5 g/l glucose) and cultivated over 7 days until full confluency was reached. Cell number and viability in all experiments were determined by trypan blue exclusion $(\mathrm{n}=4)$.

Counterflow centrifugal elutriation (CCE) was performed for the separation of the cells according to their physical size (Beckmann J6-MC with the JE-5.0 rotor; 5 ml-standard elutriation chamber, Beckman Coulter, Germany). Small-sized MSC were separated from the primary heterogeneous population. After cell separation, proliferation activity of the cells was estimated as described above.

\section{Results}

Long-term cultivation of UC-MSC under hypoxia revealed higher proliferation activity of the cells without changes in morphology when compared to ambient (21\%) oxygen concentration (Fig 1A).

High glucose concentration inhibited cell growth under ambient oxygen concentration. Hypoxic 


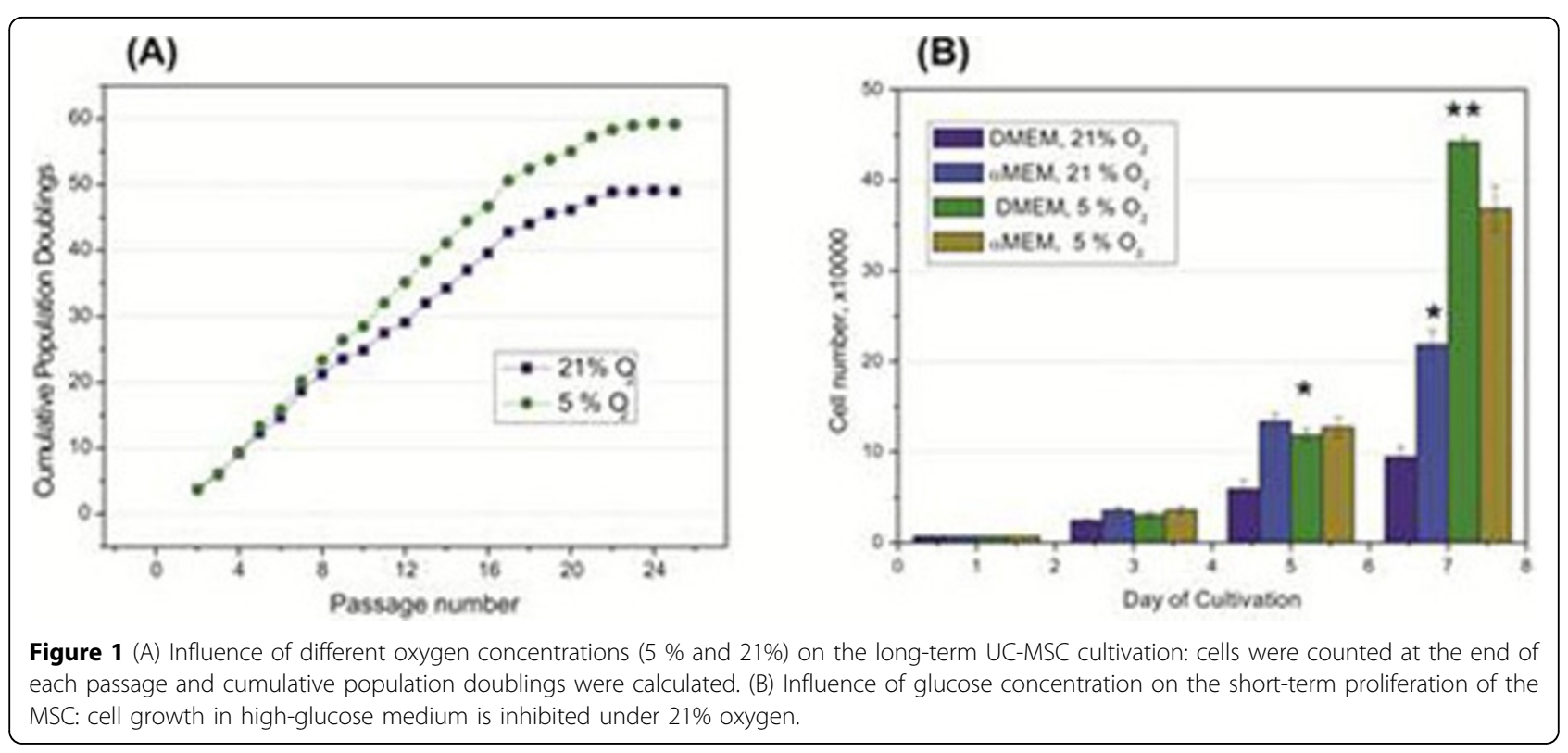

conditions, however, significantly increased proliferation of UC-MSC both, in high- and low-glucose culture medium (Fig.1B).

\section{Conclusions}

Application of MSC in regenerative medicine as cell suspensions or as a part of tissue engineered implant requires large amount of cells of high quality. MSC expansion under physiological conditions allows obtaining higher cell numbers in a shorter period of time. Also the glucose concentration in medium should be close to that in vivo. High amounts of glucose inhibit cell proliferation in ambient oxygen concentrations. In hypoxic conditions MSC proliferate better and retain their ability to differentiate. We conclude that GMPconform cultivation of MSC with allogenic human serum under physiological oxygen concentrations as well as isolation of actively dividing cells may increase the efficiency of the cell expansion for further therapeutic applications.

\section{Acknowledgements}

This work was supported by the state of Lower Saxony, DFG Project "GMPModel Lab Tissue Engineering", BMWi Project KF22501101SB9 "Frozen Cells"

\section{Author details}

'Leibniz University Hannover, Institute of Technical Chemistry, Callinstr. 5, D30167 Hannover. ${ }^{2}$ Hannover Medical School, Klinik für Frauenheilkunde und Geburtshilfe, AG Biochemie und Tumorbiologie, Carl-Neuberg-Str. 1, D-30625 Hannover.

Published: 22 November 2011

\section{References}

1. Ma T: Mesenchymal stem cells: From bench to bedside. World J Stem Cells 2:13-17.
2. Fong CY, Richards M, Manasi N, Biswas A, Bongso A: Comparative growth behaviour and characterization of stem cells from human Wharton's jelly. Reprod Biomed Online 2007, 15:708-718.

3. Majore I, Moretti P, Stahl F, Hass R, Kasper C: Growth and differentiation properties of mesenchymal stromal cell populations derived from whole human umbilical cord. Stem Cell Rev 7:17-31.

4. Lavrentieva A, Majore I, Kasper C, Hass R: Effects of hypoxic culture conditions on umbilical cord-derived human mesenchymal stem cells. Cell Commun Signal 8:18.

doi:10.1186/1753-6561-5-S8-P88

Cite this article as: Lavrentieva et al: Strategies in umbilical cord-derived mesenchymal stem cells expansion: influence of oxygen, culture medium and cell separation. BMC Proceedings 2011 5(Suppl 8):P88.

\section{Submit your next manuscript to BioMed Central} and take full advantage of:

- Convenient online submission

- Thorough peer review

- No space constraints or color figure charges

- Immediate publication on acceptance

- Inclusion in PubMed, CAS, Scopus and Google Scholar

- Research which is freely available for redistribution 